\title{
Immobilization of Glucose Oxidase on Polypropylene Micro Test Plate
}

\author{
Azmi Naqvia ${ }^{a}$, Dinesh C. Sharma ${ }^{b}$ \\ ${ }^{a}$ Women Scientist (WOS B, DST), Department of Zoology, Km. Mayawati Government Girls P.G. College, \\ Badalpur, Gautam Budha Nagar, Uttar Pradesh, India \\ ${ }^{b}$ Mentor/Supervisor, Associate. Professor and Head, Department of Zoology, Km. Mayawati Government Girls \\ P.G. College, Badalpur, Gautam Budha Nagar, Uttar Pradesh, India
}

\begin{abstract}
Article Info

Volume 7, Issue 6

Page Number: 349-353

Publication Issue :

November-December-2020

Article History

In this paper, we report a precise, reliable, cost effective and sensitive method of immobilization of Glucose oxidase GOx) onto polypropylene microtest plate $(\mathrm{PP} \mu \mathrm{TP})$. Assaying of the immobilized enzyme is carried out by spectrophotometer free image based method. $\mathrm{PP} \mu \mathrm{TP}$ acts as a mini reaction and analysis device, scanner as an image capturing instrument and color saturation as an image analytical tool for image - based assay of immobilized GOx.
\end{abstract}

Accepted : 01 Dec 2020

Published : 15 Dec 2020

Keywords : Immobilization; Glucose oxidase; Image based analysis

\section{INTRODUCTION}

Biocatalysis of redox enzymes has fascinated escalating attention for development of electronic biomaterials and devices for industrial, clinical and environmental applications [1]. One of the enzymes which are being extensively used is glucose oxidase (GOx). The GOx is widely used as a reagent in medical diagnostics [2,3], especially for determination of glucose in blood. However, a major problem with the enzymatic methods is the high cost of the enzyme itself. Immobilized enzyme technology has been used to solve the problem [4]. The use of immobilized enzymes is now a routine process for the manufacture of many industrial products in the pharmaceutical, chemical and food industry [5]. The use of the immobilized enzyme has provided significant advantages over a chemical process. In general, all enzymatic reactions can benefit from the immobilization, however, the final choice to use them in immobilized form depends on the economic evaluation of costs associated with their use versus benefits obtained in the process. It can be concluded that the benefits are rather significant, since the use of immobilized enzymes in industry is increasing [5]

Typically, most of the clinical assays are carried out in a microtiter plate and the color developed after enzyme- substrate interaction is quantified by a spectrophotometer which is an expensive instrument [6]. Also, it requires substantial quantity of an analyte which is often precious or not affordable. Imagebased biochemical assay could be a potentially useful solution for low cost assay system as it does not require costly spectrophotometer or ELISA reader. Prerequisites for image- based assay devices include: 
(i) mini reaction and analysis device, (ii) image capturing technique and (iii) image analytical tool [7]

Recently, we have developed a new assay platform for image-based analysis that is devoid of or at least reduces the background color of the image so as to give results without ambiguity. Here we have made polypropylene microtest plate $(\mathrm{PP} \mu \mathrm{TP})$ from polypropylene sheet which is hydrophobic, inert and does not bind biomolecule through absorption. The advantages of $\mathrm{PP} \mu \mathrm{TP}$ as a mini reaction analysis device for image-based analysis includes (i) it can be cut into any shape or size according to experimental needs (ii) It is made of one of the cheapest polymers polypropylene, (iii) being white it gives excellent contrast against colored substance and the image can be taken easily.[7]

In the recent work, we have used $\mathrm{PP} \mu \mathrm{TP}$ as a mini reaction and analysis device, scanner as an image capturing instrument and color saturation as an image analytical tool for image - based assay for immobilizing GOx.

\section{MATERIALS AND METHODS}

Horseradish peroxidase and glucose oxidase were purchased from Sigma, USA. $\mathrm{H}_{2} \mathrm{O}_{2}$, Ophenylenediamine, methanol, and glucose were of analytical grade and purchased from either Glaxo or Merck, India. FNAB was prepared from 4-fluoro-3nitroaniline through the diazotization reaction as reported earlier (8). FNAB is also commercially available from Aldrich Chemical Co., USA. Photoirradiation was carried out at a wavelength of $365 \mathrm{~nm}$ in a Model 2400 UV stratalinker (Stratagene, USA) fitted with five $15-\mathrm{W}$ tubes.

All solutions were freshly prepared in triple-distilled water before use. Absorbance values are expressed as means SD of three determinations. Substrate-Dye Buffer A freshly prepared solution containing $12 \mathrm{ml}$ of citrate buffer $(0.025 \mathrm{M}$ citric acid and $0.05 \mathrm{M}$ $\mathrm{Na}_{2} \mathrm{HPO}_{4}$. 2H2O, pH 5), $5 \mathrm{l}$ of $\mathrm{H}_{2} \mathrm{O}_{2}(30 \% \mathrm{w} / \mathrm{v})$, and 4 mg of o-phenylenediamine was used.

\section{EXPERIMENTAL METHODS}

\section{Preparation of 1- fluoro-2-nitro-4-azidobenzene (FNAB)}

$\mathrm{NaNO}_{2}$ solution (24 g/ $60 \mathrm{ml}$ of water) was added dropwise to the clear and cooled solution of (50 g) 4fluoro - 3-nitroaniline which was dissolved in the mixture of $325 \mathrm{ml}$ warm concentrated $\mathrm{HCl}$ and $60 \mathrm{ml}$ water and filtered while hot. After this, the reaction mixture was stirred continuously at a temperature of about $-20^{\circ} \mathrm{C}$. After the addition, of the above reagents the reaction mixture was stirred for additional $15 \mathrm{~min}$ followed by dropwise addition of $\mathrm{NaN}_{3}(22 \mathrm{~g} / 80 \mathrm{ml}$ water) to the reaction mixture. The temperature was maintained at around $-20{ }^{\circ} \mathrm{C}$. After the addition, it was stirred for another $15 \mathrm{~min}$. Yellow product was formed which was filtered and washed in ice-cold water. The product was recrystallized from light petroleum to give $36.5 \mathrm{~g}$ needle-shaped, straw-colored crystals of 1- fluoro-2-nitro-4-azidobenzene (IUPAC: 4-azido-1-fluoro- 2-nitrobenzene), mp. $52{ }^{\circ} \mathrm{C}$. FNAB was stored in dark in a loosely capped bottle at $4{ }^{\circ} \mathrm{C}$ in a refrigerator.

\section{Preparation of a polypropylene microtest plate (PP $\mu \mathrm{TP})$}

White polypropylene sheet $(0.8 \mathrm{~mm}$ thick $)$ was purchased locally and cut into a strip having dimension of $7.8 \mathrm{~cm}$ in length and $3.5 \mathrm{~cm}$ in width. On the strip, array of test zones Chapter $2 \mathrm{PP} \mu \mathrm{TP}$ and novel image - based analysis device 31 (small cavities) were made by mildly pressing or hammering with a blunt end iron rod. Each cavity was separated by 0.5 
$\mathrm{cm}$. Volume of the liquid a test zone can hold is 8- 10 $\mu l$, nonetheless test zone of lesser volume can be made easily. Cavity of the PP $\mu$ TP had an average diameter of $3.5 \mathrm{~mm}$ and a depth of around $1 \mathrm{~mm}$. All the dimensions were measured by an electronic caliper. Uniformity of cavities was also checked by measuring their volumes using distilled water. Alternatively, it is made by plastic molding method.

\section{Preparation of activated polypropylene microtest plate $(\mathrm{APP} \mu \mathrm{TP})$ in a photochemical reaction induced by UV light}

Different concentrations of FNAB $(1,0.5,0.25,0.125$, $0.0625,0.0312$ and $0 \mathrm{mg}$ ) were dissolved in 2.5 $\mu \mathrm{l} /$ cavity of methanol and loaded onto the cavities of $\mathrm{PP} \mu \mathrm{TP}$. The plate was kept for $5 \mathrm{~min}$ in dark hood for complete evaporation of methanol from the wells. The plates were then exposed to UV light for $20 \mathrm{~min}$ at a wavelength of $365 \mathrm{~nm}$ in UV Stratalinker fitted with five $15-\mathrm{W}$ tubes. The plate was then washed with methanol and air dried.

\section{Immobilization of Glucose Oxidase onto APP $\mu \mathrm{TP}$.}

Glucose oxidase (100 ng/10 $\mu$ l of PBS) were loaded into the photolinker treated and into the untreated wells of microtest plate. Immobilization of GOx was carried out at $37^{\circ} \mathrm{C}$ for $45 \mathrm{~min}$. The wells were then treated with $9 \%$ glucose solution $(6 \mu \mathrm{l} /$ well $)$ and kept for $10 \mathrm{~min}$ at room temperature. Then $2 \mu \mathrm{l}(100 \mathrm{ng}$ ) of horseradish peroxidase solution per well was added, and the wells were again kept for $2 \mathrm{~min}$ at room temperature. After addition of $2 \mu \mathrm{l}$ of substrate-dye buffer, the plate was scanned on a desktop scanner [7]. All the experiments were performed in triplicates.

\section{RESULTS AND DISCUSSIONS}

$\mathrm{PP} \mu \mathrm{TP}$ is made up of polypropylene sheet which is hydrophobic, inert and does not bind biomolecule through absorption; hence $\mathrm{PP} \mu \mathrm{TP}$ is not suitable for assays where biomolecule immobilization is required. Therefore, for such assay the test zones are activated using a photolinker, FNAB as described earlier (8). Thus, in APP $\mu \mathrm{TP}$ only a desired biomolecule is immobilized in the test zone by covalent bonding. Mechanism of activation of $\mathrm{PP} \mu \mathrm{TP}$ is shown in figure 1. The method consists of exposing a FNAB-coated polymer surface under UV light to generate a highly reactive nitrene, which inserts into the polymer, forming a covalent linkage. The fluoro group of the transformed polymer is responsible for binding a protein ligand. It is very likely that this method will be applicable to any polymer surface.

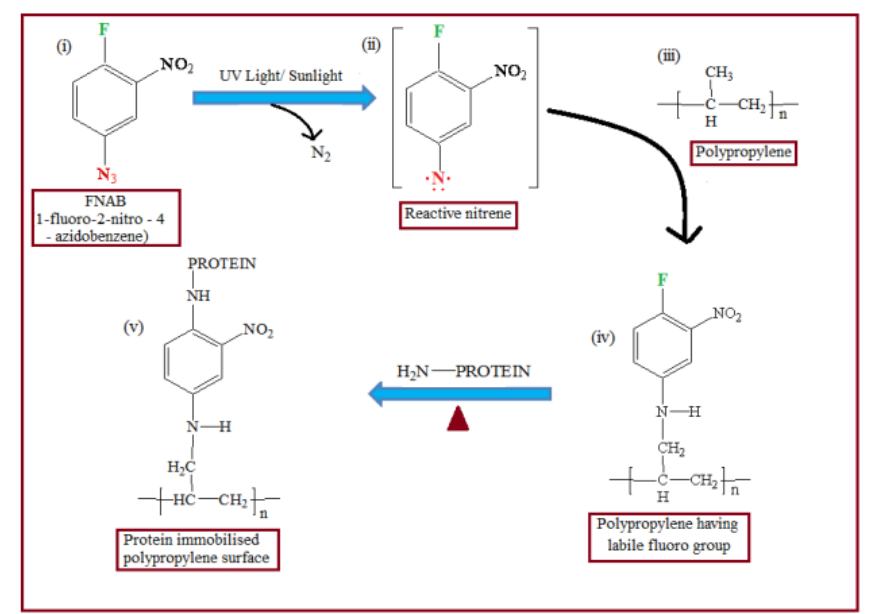

Figure 1. Mechanism of activation of $\mathrm{PP} \mu \mathrm{TP}$

The optimum amount of photolinker and its optimum exposure to UV light were determined for preparing activated $\mathrm{PP} \mu \mathrm{TP}$ that allowed the best enzyme immobilization. For activation of the PP $\mu$ TP surface, the results displayed a pattern, which was akin to that of polystyrene surface, as reported in our earlier communication (8). Maximum activation was obtained when $0.0625 \mathrm{mg}$ FNAB per well was used at an optimum exposure time of $20 \mathrm{~min}$, beyond which the surface became discolored. However, control experiments (without FNAB) showed no significant absorbance (Fig. 2 and 3) 


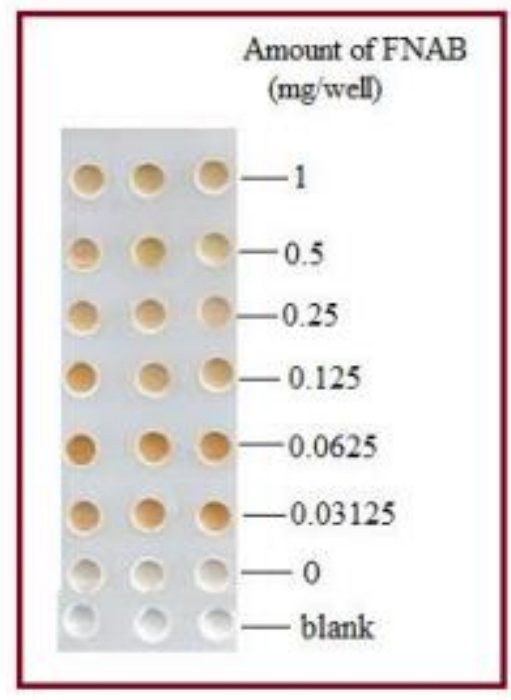

Figure 2. Optimization of amount of FNAB for activation of a $\mathrm{PP} \mu \mathrm{TP}$.

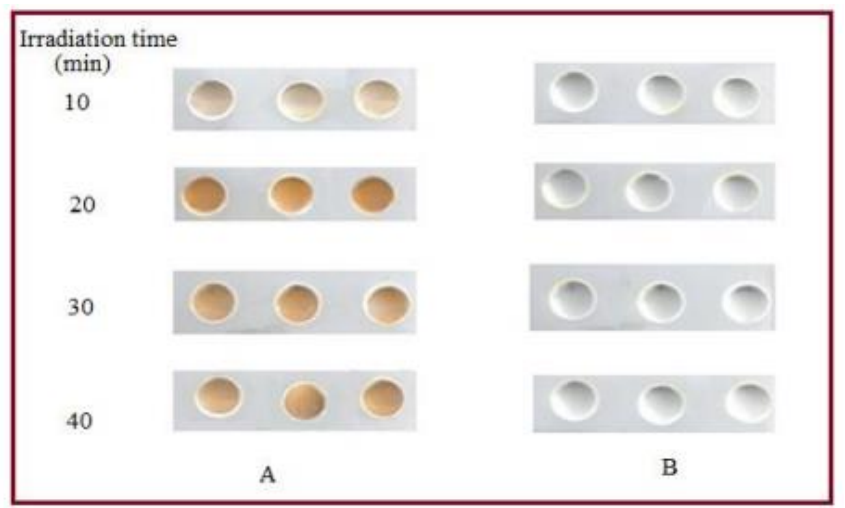

Figure 3: Immobilization of GOx on APP $\mu \mathrm{TP}$ and its assay. (B) Control experiment without enzyme.

The plates filled with solution were scanned using desktop scanner to get an image (figure 4). To do so, plates were turned upside down and scanned; due to surface tension, solution remained in the cavities without any spillage (7). The image of PP $\mu$ TP filled with solution is clear and uniform.

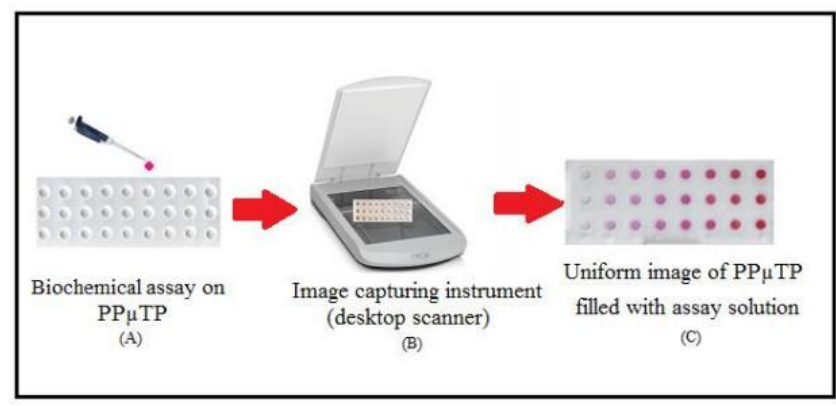

Figure 4: (A) Assay solution in the cavities of $\mathrm{PP} \mu \mathrm{TP}$ (B) scanning the plate $(C)$ uniform image.

\section{CONCLUSION}

There are many different methods used for enzyme immobilization, but simple and cost-effective methods are always preferable. The most used methods are based on physical immobilization (adsorption or physical entrapment) and chemical immobilization (covalent binding and cross linking). Precise, reliable, cost effective and sensitive method of immobilization of Glucose oxidase GOx) onto polypropylene microtest plate $(\mathrm{PP} \mu \mathrm{TP})$ is successfully carried out and can open avenues for immobilization of other enzymes of medical purposes.

\section{ACKNOWLEDGMENT}

A.N thanks the Department of Science and Technology, Government of India for the award of a "Women Scientist (WOS B)" Fellowship.

\section{VII.REFERENCES}

[1]. Katz E et al 2004, Nanoparticles: From Theory to Applications (Ed.: G. Schmid), Wiley-VCH, Weinheim, Germany.

[2]. Iwuoha E I and Smyth M R 1994 Anal. Proc. 31 19.

[3]. Atia K S and Al El-Batal 2005 J. Chem. Technol. and Biotechnol. 80805

[4]. Ma J et al 2007 J. Sep. Sci .30 3050. 
[5]. Alessandra B and Simona S. 2019. Industrial applications of immobilized enzymes-A review. Molecular Catalysis, Volume 479, December, 110607.

[6]. Sakamoto S et. al. 2018. J Nat Med.; 72(1): 3242.

[7]. Parween S. and Nahar, P. 2013. Biosensors and Bioelectronics, 48: 287-292.

[8]. Azmi N et. al. 2002, Analytical Biochemistry 306, 74-78.

\section{Cite this article as :}

Azmi Naqvi, Dinesh C. Sharma, " Immobilization of Glucose Oxidase on Polypropylene Micro Test Plate", International Journal of Scientific Research in Science and Technology(IJSRST), Print ISSN : 2395-6011, Online ISSN : 2395-602X,Volume 7, Issue 6, pp.349353, November-December-2020. Available at doi $\quad$ : https://doi.org/10.32628/IJSRST207650

Journal URL : http://ijsrst.com/IJSRST207650 